\title{
A vegetation control on seasonal variations in global atmospheric mercury
}

Jiskra, Martin¹,2; Sonke, Jeroen E. ; Obrist, Daniel ${ }^{3}$; Bieser, Johannes; ${ }^{4}$ Ebinghaus, Ralf; ${ }^{4}$ Myhre, Cathrine Lund ${ }^{5}$; Pfaffhuber, Katrine Aspmo 5; Wängberg, Ingvar6; Kyllönen, Katriina7; Worthy, Doug8; Martin, Lynwill G. ${ }^{9}$; Labuschagne Casper9; Mkololo, Thumeka'; Ramonet, Michel $^{10}$; Magand, Olivier ${ }^{11}$; and Dommergue, Aurélien ${ }^{11}$

${ }^{1}$ Geosciences Environnement Toulouse, CNRS/OMP/Université de Toulouse, 14 Avenue Edouard Belin, 31400 Toulouse, France.

2Environmental Geosciences, University of Basel, Bernoullistr. 30, 4056 Basel, Switzerland ${ }^{3}$ Department of Environmental, Earth, and Atmospheric Sciences, University of Massachusetts, Lowell, MA 01854, USA

${ }^{4}$ Helmholtz Zentrum Geesthacht, Institute of Coastal Research, 21502 Geesthacht, Germany ${ }^{5}$ NILU - Norwegian Institute for Air Research, 2027 Kjeller, Norway ${ }^{6}$ IVL Swedish Environmental Research Institute, Box 530 21, SE-400 14 Gothenburg, Sweden 7Finnish Meteorological Institute, Atmospheric Composition Research, 00560 Helsinki, Finland ${ }^{8}$ Environment and Climate Change Canada, Climate Research Division, Toronto, Canada ${ }^{9}$ Cape Point GAW Station, South African Weather Service, 11 Jan Cilliers Street, Stellenbosch, South Africa

10 Laboratoire des Sciences du Climat et de l'Environnement, LSCE-IPSL (CEACNRSUVSQ),Université Paris-Saclay, 91191 Gif Sur Yvette, France 11Univ. Grenoble Alpes, CNRS, IRD, IGE, 38000 Grenoble, France 


\begin{abstract}
Anthropogenic mercury emissions are transported through the atmosphere as gaseous elemental mercury $(\mathrm{Hg}(0))$ prior to deposition to Earth's surface. Strong seasonality in atmospheric $\mathrm{Hg}(0)$ concentrations in the Northern Hemisphere has been explained by two factors: anthropogenic $\operatorname{Hg}(0)$ emissions are thought to peak in winter due to higher energy consumption, and atmospheric oxidation rates of $\mathrm{Hg}(0)$ are faster in summer. Oxidationdriven $\operatorname{Hg}(0)$ seasonality should be equally pronounced in the Southern Hemisphere, which is inconsistent with observations of constant year-round $\operatorname{Hg}(0)$ levels. Here, we assess the role of $\mathrm{Hg}(0)$ uptake by vegetation as an alternative mechanism for driving $\mathrm{Hg}(0)$ seasonality. We find that at terrestrial sites in the Northern Hemisphere, $\mathrm{Hg}(0)$ co-varies with $\mathrm{CO}_{2}$, which is known to exhibit a minimum in summer when $\mathrm{CO}_{2}$ is assimilated by vegetation. The amplitude of seasonal oscillations in atmospheric $\operatorname{Hg}(0)$ concentration increases with latitude and is larger at inland terrestrial sites than at coastal sites. Using satellite data, we find that the photosynthetic activity of vegetation correlates with $\mathrm{Hg}(0)$ levels at individual sites and across continents. We suggest that terrestrial vegetation acts as a global $\operatorname{Hg}(0)$ pump, which can contribute to seasonal variations of atmospheric $\mathrm{Hg}(0)$, and that decreasing $\mathrm{Hg}(0)$ levels in the Northern Hemisphere over the past 20 years can be partly attributed to increased terrestrial net primary production.
\end{abstract}


Gaseous elemental mercury $(\mathrm{Hg}(0))$ is the dominant form of natural and anthropogenic $\mathrm{Hg}$ emissions and is transported globally through the atmosphere. $1 \mathrm{Hg}$ deposition to earth surfaces occurs either by direct $\mathrm{Hg}(0)$ dry deposition or after oxidation to reactive $\mathrm{Hg}(\mathrm{II})$, which is scavenged from the atmosphere by wet and dry deposition. $\frac{2}{2}$ addition to primary anthropogenic emissions, $\mathrm{Hg}$ is also re-emitted as $\mathrm{Hg}(0)$ from land and ocean surfaces to the atmosphere after reduction of $\mathrm{Hg}(\mathrm{II})$ pools in terrestrial and aquatic ecosystems. $\underline{\underline{2}}$

The short-term balance between Hg emission, deposition and re-emission processes governs diurnal and seasonal $\mathrm{Hg}(0)$ variations. For example, strong seasonal variations in atmospheric $\mathrm{Hg}(0)$ concentration have been described for most background sites in the temperate Northern Hemisphere (NH) with peaks in winter and minima in summer. $\frac{3-6}{6}$ Two hypotheses for the observed $\mathrm{Hg}(0)$ seasonality are commonly proposed. The first hypothesis assumes that $\mathrm{Hg}(0)$ variations are directly related to primary anthropogenic $\mathrm{Hg}(0)$ emissions from coal combustion which are thought to be higher in winter due to higher energy demands for heating. $\underline{3}$ Global $\mathrm{Hg}$ models have not yet been able to test this hypothesis, as current anthropogenic Hg emission inventories have no seasonal resolution and are kept constant throughout the year in models. $\frac{7-9}{}$ The second hypothesis suggests that atmospheric $\operatorname{Hg}(0)$ oscillations are due to variations in atmospheric $\mathrm{Hg}(0)$ oxidation rate and subsequent $\mathrm{Hg}(\mathrm{II})$ deposition, which are both highest in summer in global $\mathrm{Hg}$ models. $\frac{7-10}{}$ Models incorporating atmospheric $\operatorname{Hg}(0)$ oxidation simulate equally pronounced (amplitudes of approx. 18\%) seasonal $\mathrm{Hg}(0)$ variations in both Hemispheres. $\mathrm{Hg}(0)$ measurements at temperate sites in the Southern Hemisphere (SH), however, are constant with no seasonal oscillations. 6,11 Conversely, methane concentrations in the $\mathrm{SH}$, for which atmospheric oxidation by $\mathrm{OH}$ radicals represents the most important sink, do show strong seasonal variations. $\frac{12}{2}$ The absence of $\mathrm{Hg}(0)$ seasonality in the $\mathrm{SH}$ questions the dominant role of atmospheric $\mathrm{Hg}(0)$ oxidation.

Foliar uptake of atmospheric $\mathrm{Hg}(0)$ has long been recognized as a potentially inportant pathway for atmospheric Hg deposition. $\underline{13} \underline{14}$ The magnitude of terrestrial-atmosphere net $\mathrm{Hg}(0)$ exchange (foliar $\mathrm{Hg}(0)$ uptake - $\mathrm{Hg}(0)$ re-emission) however has been debated with studies suggesting a net emission of $\operatorname{Hg}(0) \underline{15-18}$ and others suggesting net $\operatorname{Hg}(0)$ deposition. $\frac{19}{}$ A recent review of $\mathrm{Hg}(0)$ flux measurements over terrestrial surfaces concludes that there is no consensus whether terrestrial ecosystems are a net sink or source for $\mathrm{Hg}(0)$ (-513 to 1651 $\mathrm{Mg} \mathrm{a}^{-1}, 25$ to 75 percentile). $\underline{20}$ Most $\mathrm{Hg}(0)$ flux studies however focused on soil re-emission, and thus neglected foliar $\operatorname{Hg}(0)$ exchange. $\underline{20}$ 
There are several lines of evidence for net $\operatorname{Hg}(0)$ deposition to terrestrial ecosystems that all invoke direct vegetation uptake of atmospheric $\mathrm{Hg}(0)$. First, foliage tissue $\mathrm{Hg}$ concentrations increase continously over the growing season, implying that $\operatorname{Hg}(0)$ is taken up by vegetation through gas exchange and sequestered in leaf tissue. $\underline{14, \underline{21}}$ Structurally incorporated $\mathrm{Hg}$ in leaf tissue derived from atmospheric $\mathrm{Hg}(0)$ therefore likely has a lower re-

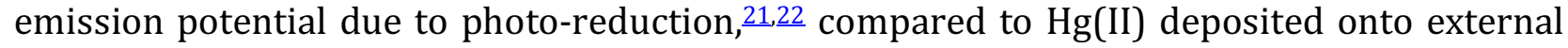
leaf surfaces. $\underline{23}$ Second, global litterfall $\mathrm{Hg}$ deposition to soils - representing $\operatorname{Hg}(0)$ net uptake by foliage - is estimated to be $1000-1200 \mathrm{Mg} \mathrm{yr}^{-1} \underline{17} \underline{24}$ representing half of primary anthropogenic emissions. $\underline{25}$ Third, vegetation and soil $\mathrm{Hg}$ stable isotope signatures, which discern foliar $\mathrm{Hg}(0)$ uptake from $\mathrm{Hg}(\mathrm{II})$ wet deposition, put firm constraints on vegetation $\mathrm{Hg}(0)$ uptake dominating (50-80\%) Hg net deposition at terrestrial sites. $\underline{22} \underline{26-28}$

Here, we investigate the role of vegetation $\mathrm{Hg}(0)$ uptake in modulating global atmospheric $\operatorname{Hg}(0)$ distribution and seasonality. We compare the atmospheric dynamics of $\mathrm{Hg}(0)$ with those of $\mathrm{CO}_{2}$ - a tracer for gas exchange by vegetation - for which seasonal oscillations in the Northern Hemisphere $(\mathrm{NH})$ are attributed to the balance of $\mathrm{CO}_{2}$ assimilation and respiration during the year. $.29-31$

\section{Correlation of $\mathrm{Hg}(0)$ and $\mathrm{CO}_{2}$ seasonality}

We investigated multi-year time series of $\mathrm{Hg}(0)$ and $\mathrm{CO}_{2}$ at seven $\mathrm{NH}$ and $\mathrm{SH}$ background sites (mean $\mathrm{Hg}(0)<2 \mathrm{ng} / \mathrm{m}^{3}$ ) and $\mathrm{Hg}(0)$ at an additional 43 global sites. Multi-year $\mathrm{Hg}(0)$ and $\mathrm{CO}_{2}$ observations of the five NH background sites, normalized for linear long-term trends, show seasonal variations with highest concentrations in winter and minima in summer and fall (Fig. 1, S1, S3, S5 and S6). For all NH sites including both of inland and coastal sites, we found a significant positive correlation between multi-year averages of monthly $\mathrm{Hg}(0)$ and $\mathrm{CO}_{2}$ concentrations normalized for long-term trends (Birkenes, Norway $\left(R^{2}=0.53, p=0.003\right)$, Schauinsland, Germany ( $\left.\mathrm{R}^{2}=0.40, \mathrm{p}=0.012\right)$, Mace Head, Ireland $\left(\mathrm{R}^{2}=0.70, \mathrm{p}<0.001\right)$, Pallas, Finland $\left(\mathrm{R}^{2}=0.45, \mathrm{p}=0.007\right)$ and Egbert, Canada $\left(\mathrm{R}^{2}=0.76, \mathrm{p}<0.001\right)$, Fig. S2). In the $\mathrm{SH}$, the available data are from two coastal sites, Cape Point (South Africa) and Amsterdam Island (France), with the latter surrounded by $3000 \mathrm{~km}$ of ocean. Both SH sites show small day-today variability, small diurnal variation, small seasonal amplitudes in $\mathrm{CO}_{2}(<3 \mathrm{ppm},<1 \%)$ and $\operatorname{Hg}(0)\left(<0.1 \mathrm{ng} / \mathrm{m}^{3},<10 \%\right)$ (Fig. 1) and no significant correlation between the two trace gases (Fig. S2). This suggests low anthropogenic contributions (i.e., no pollution plumes) resulting in $\operatorname{Hg}(0)$ distribution that is relatively constant throughout the day and seasons. 
Two thirds of the primary anthropogenic emissions are to the $\mathrm{NH}, \underline{32}$ which is the main explanation for the large interhemispheric gradient in $\mathrm{Hg}(0)$ concentrations. 6 We find that the interhemispheric gradient $\left(\Delta \mathrm{Hg}_{\left.45^{\circ} \mathrm{N}-45^{\circ} \mathrm{S}\right)}\right.$ is largest in February $\left(0.68 \mathrm{ng} / \mathrm{m}^{3}\right)$ and smallest in September $\left(0.36 \mathrm{ng} / \mathrm{m}^{3}\right)$ with a yearly average of $0.52 \mathrm{ng} / \mathrm{m}^{3}$ (Fig 2A). Yet seasonal amplitudes of $\mathrm{Hg}(0)$ measurements at temperate $\mathrm{NH}$ background sites are much larger than in the $\mathrm{SH}$, averaging $0.39 \mathrm{ng} / \mathrm{m}^{3}$ (equivalent to $25 \%$ of the average annual $\mathrm{Hg}(0)$ concentration of $\left.1.5-1.7 \mathrm{ng} / \mathrm{m}^{3}\right), \underline{6}$ and were 6 times larger than the corresponding $\mathrm{CO}_{2}$ amplitudes (4\%). Excluding Polar sites (see below), we find a positive correlation $\left(R^{2}=0.78, p<0.01\right)$ between seasonal $\mathrm{Hg}(0)$ (Sep-Feb) and $\mathrm{CO}_{2}$ (Aug-Feb) amplitudes (Fig. 2C). Amplitudes of seasonal $\mathrm{CO}_{2}$ oscillations are largest at high NH latitudes and decrease towards the south with minimal oscillations in the $\mathrm{SH}$, which has been related to smaller land masses in the $\mathrm{SH}$ and ecosystems serving as net sinks in summer and net sources in winter. $29-31$ We find a significant correlation between the seasonal $\mathrm{Hg}(0)$ amplitudes of all background sites $(\mathrm{n}=38)$ and latitude $\left(\mathrm{R}^{2}=0.42\right.$, $\mathrm{p}<0.001$, Fig. 2B). However, $\mathrm{Hg}(0)$ amplitudes are confounded by additional factors. For example, we explain the lower amplitude at Egbert (Ca) by relatively high contributions of polluted air masses throughout the year (Fig. S12). Comparing all investigated sites, we find significantly higher $\mathrm{Hg}(0)$ amplitudes at inland background sites compared to coastal sites, both for Europe (0.39 ng/m³ vs. $0.25 \mathrm{ng} / \mathrm{m}^{3}, \mathrm{n}=13, \mathrm{p}<0.05,2$-sided t-test) and North America (0.41 ng/m³ vs. $0.27 \mathrm{ng} / \mathrm{m}^{3}, \mathrm{n}=18, \mathrm{p}<0.05,2$-sided t-test). A special case is a different seasonality of $\mathrm{Hg}(0)$ in the Arctic, which is characterized by well-documented spring minima due to sea-salt induced atmospheric mercury depletion events (AMDEs) and an unusual summertime maximum. $\frac{33}{3}$ Observations from SH terrestrial background sites are few, yet the first data from Bariloche, Patagonia (Ar) revealed seasonal $\mathrm{Hg}(0)$ oscillations with minima in SH summer and autumn. $\underline{34}$

If seasonal variations in atmospheric $\operatorname{Hg}(0)$ were mainly due to oxidation rates and ocean re-emission, $\underline{7-9}$ we would expect higher $\mathrm{Hg}(0)$ amplitudes at coastal sites and in the $\mathrm{SH}$, which is contrary to the patterns described above. The fact that the highest seasonal amplitudes are observed at inland terrestrial background sites - along with similar patterns observed for $\mathrm{CO}_{2}-$ is consistent with an important role of vegetation $\mathrm{Hg}(0)$ uptake in modulating global atmospheric $\mathrm{Hg}(0)$ concentrations. Individual ecosystem-scale studies have reported enhanced $\mathrm{Hg}$ deposition fluxes during vegetation growth periods $\underline{22, \underline{35}}$ resulting in lower local atmospheric $\operatorname{Hg}(0)$ levels over vegetated surfaces. $\underline{27} \underline{36}, \underline{37}$ The $\mathrm{NH}$ is not only more populated but also has a much larger land mass (39\% land) compared to the SH (19\% 
land), resulting in higher vegetation $\operatorname{Hg}(0)$ uptake which may explain the weaker interhemispheric gradient during the $\mathrm{NH}$ growing season.

Most $\mathrm{NH}$ sites reveal a notable 1-month offset in $\mathrm{Hg}(0)$ summertime minima (Sep) compared to $\mathrm{CO}_{2}$ (Aug) (Fig. S3, S6). Diurnal patterns between $\mathrm{Hg}(0)$ and $\mathrm{CO}_{2}$ are anticorrelated during summer, but not in winter (Fig. S4; See SI for details). Differences in diurnal oscillations (Fig. S4) and later seasonal minima of $\mathrm{Hg}(0)$ relative to $\mathrm{CO}_{2}$ suggest that $\mathrm{Hg}(0)$ uptake by vegetation continues during periods of net $\mathrm{CO}_{2}$ respiration (i.e., nighttime and fall) when $\mathrm{CO}_{2}$ ecosystem exchange turns from net assimilation (sink) to net respiration (source). $\underline{\underline{38}}$ It is interesting to note that $\mathrm{Hg}(0)$ hence follows a similar behavior as carbonyl sulfide (COS), a tracer for stomata conductance of vegetation, for which seasonal patterns are strongly related to $\mathrm{CO}_{2}$ but diurnal variations are decoupled from $\mathrm{CO}_{2} \cdot \underline{39} \underline{40}$ This suggests that vegetation $\mathrm{Hg}(0)$ uptake is controlled by gas exchange as approximated by $\mathrm{CO}_{2}$ here. Net ecosystem $\mathrm{CO}_{2}$ respiration however does not result in corresponding losses of $\mathrm{Hg}(0)$, which is supported by flux measurements at individual sites. $\underline{35}$ Observed $\operatorname{Hg}(0)$ concentration minima in September may be further amplified by a shallower planetary boundary layer (PBL) in autumn leading to a reduced mixing of surface air with global background air. $\underline{31}$

\section{Variations in $\mathrm{Hg}(0)$ vs. vegetation activity}

We compared multi-year averages of monthly $\mathrm{Hg}(0)$ concentrations with the satellite-based Normalized Differenced Vegetation Index (NDVI), representing the vegetation photosynthetic activity at the location of the $44 \mathrm{NH}$ monitoring sites $\left(0.1^{\circ}\right.$ resolution). We find a significant correlations between monthly $\mathrm{Hg}(0)$ concentrations and NDVI for 22 of the 44 investigated sites. For the $\mathrm{NH}$ background sites with corresponding $\mathrm{Hg}(0)$ and $\mathrm{CO}_{2}$ data, NDVI significantly correlated with both trace gases (Fig. 3), with the exception of $\operatorname{Hg}(0)$ at one site (Schauinsland, De). For example, at Pallas, Fi NDVI was able to explain $69 \%$ and $82 \%$ of seasonal $\mathrm{Hg}(0)$ and $\mathrm{CO}_{2}$ variation, respectively. The correlations between $\mathrm{Hg}(0)$ and NDVI were strongest at background sites in Canada ( $\mathrm{R}^{2}>0.75$ for e.g. Burnt Island, or Kejimkijuk, Fig. S8, Table S2), Scandinavia ( $\mathrm{R}^{2}>0.6$ for e.g. Andoya, Bredkäle, or Vavihill, Fig. S9, Table S3) as well as for Mountain sites in China ( $\mathrm{R}^{2} \approx 0.5$ for e.g. Mt. Damai, Mt. Leigong, Mt. Chanbai, Fig. S10, Table S4). For urban sites in North America (e.g. Salt Lake City, Houston or Detroit, Fig. S7, Table S2) or Asia (Beijing, Nanjing, Fig. S10, Table S4) we did not find a significant correlation between $\mathrm{Hg}(0)$ and NDVI, suggesting that local anthropogenic emissions dominates $\mathrm{Hg}(0)$ levels at these urban sites. The strong correlations between $\mathrm{Hg}(0)$ and NDVI at most background sites further support the notion that vegetation uptake is responsible for $\mathrm{Hg}(0)$ 
depletion in summer months when the vegetation activity is highest (high NDVI). We therefore suggest that NDVI satellite data might be a robust parameter to estimate terrestrial $\mathrm{Hg}(0)$ uptake on spatial and temporal scales, yet field studies directly comparing $\mathrm{Hg}(0)$ fluxes with vegetation cover are needed in order to validate this approach. A recent study found a strong correlation of soil Hg pools with NDVI across western North America, $\underline{41}$ suggesting a long-term control of vegetation $\mathrm{Hg}(0)$ uptake on soil $\mathrm{Hg}$ accumulation and sequestration, which also is supported by $\mathrm{Hg}$ stable isotope data. $\underline{22,26-28}$

\section{Seasonality of anthropogenic $\mathrm{Hg}(0)$ emission}

Coal combustion represents a major primary $\mathrm{Hg}(0)$ emission source to the atmosphere. $2 \underline{2} \mathrm{We}$ estimated the seasonal variation of anthropogenic Hg emissions (Table S5) by using monthly coal consumption data reported for the United States, Europe (EU27) and China. The estimates show a peak in $\mathrm{Hg}$ emission during the cold winter months attributed to increased energy consumption for heating (Fig. 4). In North America, there is a second peak in coal consumption and thus $\mathrm{Hg}(0)$ emission during hot summer months that exceeds the winter peak and is attributed to high energy consumption for air-conditioning of buildings. $\frac{42}{\mathrm{Hg}(0)}$ concentrations measured at three urban monitoring sites in North America (Salt Lake City, Houston and Detroit) $\underline{43}, \underline{44}$ closely follow these seasonal emission estimates, including a noticeable summertime $\operatorname{Hg}(0)$ increase (Fig. 4). Regional background sites in North America, however, show consistent summertime minima (Fig. 4), which cannot be explained by anthropogenic $\mathrm{Hg}$ emissions, implying that other processes drive the lower $\operatorname{Hg}(0)$ levels in summer. Inverse modeling that optimized terrestrial-atmosphere $\mathrm{Hg}(0)$ exchange fluxes to fit observational $\mathrm{Hg}(0)$ data, suggested enhanced summertime net $\mathrm{Hg}(0)$ deposition over eastern North America ${ }^{45}$ supporting the strong role of vegetation $\mathrm{Hg}(0)$ uptake_In Europe and Asia, the anthropogenic $\operatorname{Hg}(0)$ emission estimates based on coal consumption data are highest in winter (Table S4) with no summertime increase and a seasonality similar to $\mathrm{Hg}(0)$ observations (Fig. 4). For the Waldhof site in central Europe, regional models have found a strong correlation between emission and particulate mercury but not for $\operatorname{Hg}(0) . \underline{46}$ We therefore conclude that variations in primary anthropogenic emissions alone cannot explain the observed seasonal $\mathrm{Hg}(0)$ variation in the $\mathrm{NH}$.

\section{Implications for global $\mathrm{Hg}$ cycling}

$\mathrm{Hg}(0)$ concentrations measured in the PBL at terrestrial background sites reflect both deposition and emission processes. Therefore observed $\mathrm{Hg}(0)$ oscillations must be considered 
as variations in net exchange (natural and anthropogenic emissions, vegetation uptake, and soil/vegetation re-emission). Strong depletion of atmospheric $\operatorname{Hg}(0)$ observed at terrestrial background sites in summer, despite highest solar radiation and therefore potential photoreductive re-emission, suggests that terrestrial ecosystems serve as net sinks for $\operatorname{Hg}(0)$. A dominant role of vegetation $\mathrm{Hg}(0)$ uptake over other terrestrial emission and deposition processes also reconciles terrestrial $\mathrm{Hg}$ isotope constraints, which suggest $50-80 \%$ of vegetation and soil $\mathrm{Hg}$ to derive from plant $\operatorname{Hg}(0)$ uptake.22,26-28 Considering the 20\% amplitude of seasonal $\mathrm{Hg}(0)$ oscillations and an atmospheric $\mathrm{Hg}(0)$ pool of $4800 \mathrm{Mg}$, 47 we estimate that net $\mathrm{Hg}(0)$ sequestration is on the order of $1000 \mathrm{Mg} \mathrm{a}^{-1}$ of $\mathrm{Hg}(0)$ during the vegetation period, which is in agreement with foliage/litterfall estimates of $1000-1200 \mathrm{Mg} \mathrm{a}^{-}$ $1.17 \underline{24}$ The gross foliar $\mathrm{Hg}(0)$ uptake flux is likely larger. This suggests that at least half of the annual primary anthropogenic emissions are assimilated by terrestrial vegetation, where it is efficiently retained against re-emission to the atmosphere, though susceptible to transfer via soils to continental and coastal aquatic ecosystems. .22 We suggest that the vegetation pump controls to a large extent diurnal and seasonal cycling of atmospheric $\mathrm{Hg}(0)$ in the terrestrial PBL, which has large implications for global Hg cycling and interpreting and forecasting longterm trends. The absence of $\mathrm{Hg}(0)$ seasonality observed in the $\mathrm{SH}$ seems inconsistent with our current understanding of atmospheric $\mathrm{Hg}$ redox dynamics., $, 9,47$ An important role of vegetation $\mathrm{Hg}(0)$ uptake on $\mathrm{NH} \mathrm{Hg}(0)$ seasonality may imply that atmospheric $\mathrm{Hg}(0)$ oxidation is less significant than currently assumed.

Average $\mathrm{Hg}(0)$ levels in the NH have decreased by 20-40\% between 1990 and 2010, which was recently attributed to a cumulative $30 \%\left(\approx 600 \mathrm{Mg} \mathrm{a}^{-1}\right)$ decrease in global primary anthropogenic $\operatorname{Hg}(0)$ emissions. $\underline{25}$ Over the same time period, net primary production (NPP) is thought to have increased in the $\mathrm{NH}$ by $0.13-0.15 \mathrm{Pg} \mathrm{C} \mathrm{a}^{-1} . \underline{48,49}$ Assuming median foliar $\mathrm{Hg}$ concentrations of $24 \mathrm{ng} \mathrm{g}^{-1}, \underline{17}$ we estimate that $\mathrm{Hg}(0)$ deposition by $\mathrm{NH}$ vegetation uptake today has increased by $\approx 140 \mathrm{Mg} \mathrm{a}^{-1}$ relative to 1990 . We therefore suggest that a significant fraction of the observed decrease in $\mathrm{NH}$ atmospheric $\mathrm{Hg}(0)$ concentrations can be attributed to increased vegetation uptake of $\mathrm{Hg}(0)$. Recent estimates of gross primary production (GPP), based on atmospheric COS cycling, suggested even larger increases in GPP by $31 \%$ during the twentieth century, $\underline{50}$ that may have strongly counterbalanced estimated increases in $\operatorname{Hg}(0)$ emissions. Regional reductions in vegetation cover by deforestation $\underline{51}$ or droughts $\underline{49}$, on the other hand, would weaken the vegetation $\mathrm{Hg}(0)$ pump and result in higher atmospheric $\mathrm{Hg}(0)$ concentrations. We therefore emphasize the need to incorporate seasonal and spatial variability in vegetation uptake of $\mathrm{Hg}(0)$ into global $\mathrm{Hg}$ models. In addition, trends in 
vegetation activity should be incorporated in models reconstructing past and predicting future $\mathrm{Hg}(0)$ levels. The effects of $\mathrm{Hg}(0)$ uptake by vegetation related to climate change and land-use change should be considered when discussing mitigation strategies to reduce human Hg exposure. Finally, the paradigm shift we propose regarding the importance of vegetation $\mathrm{Hg}(0)$ uptake as a $\mathrm{Hg}$ deposition pathway demands revised $\mathrm{Hg}$ deposition monitoring strategies by environmental agencies.

\section{FIGURE CAPTIONS}

Fig. 1: Time records of atmospheric $\mathrm{Hg}(0)$ and $\mathrm{CO}_{2}$ concentrations. Seasonal oscillations of atmospheric $\mathrm{Hg}(0)$ (red) and $\mathrm{CO}_{2}$ (blue) concentration at seven monitoring sites around the globe. Fine lines represent daily and bold lines represent monthly anomalies normalized for long-term linear trends. All data meeting $\mathrm{QA} / \mathrm{QC}$ criteria of the respective site are presented.

Fig. 2: Effect of latitude on $\mathbf{H g ( 0 )}$ seasonality A: Interhemispherical Gradient of $\mathrm{Hg}(0)$ at background sites $\left(<2 \mathrm{ng} / \mathrm{m}^{3}\right)$ for February and September. B: Seasonal amplitude of $\mathrm{Hg}(0)$ (September mean February mean) as a function of latitude for coastal (squares) and terrestrial (circles) sites. C: Seasonal amplitudes of $\mathrm{Hg}(0)$ (Sep-Feb) and $\mathrm{CO}_{2}$ (Aug-Feb) variation measured at 7 atmospheric sites. The error bars represent the interannual variability $(1 \sigma)$. The lines represents the linear regression of the data and the shaded area the $95 \%$ confidence area of the regression.

\section{Figure 3: Effect of vegetation activity on atmospheric $\mathrm{Hg}(0)$ and $\mathrm{CO}_{2}$ concentration. Linear} regression between multi-year averages of monthly $\mathrm{Hg}(0)$ concentration (left) or $\mathrm{CO}_{2}$ concentration (right) and vegetation activity (NDVI). lines represents the linear regression of the data and the shaded area the $95 \%$ confidence area of the regression.

Fig. 4: Seasonal variation of $\mathrm{Hg}$ emission, vegetation activity and atmospheric $\mathrm{Hg}(0)$ concentration. Seasonal variation of $\mathrm{Hg}$ emissions in gray, atmospheric $\mathrm{Hg}(0)$ concentration at terrestrial background sites $(\mathrm{Hg}(0) \mathrm{Bg})$ in blue and at urban sites $(\mathrm{Hg}(0)$ urban) in red and vegetation activity (NDVI) in green. Monthly $\mathrm{Hg}$ emission and $\mathrm{Hg}(0)$ concentrations are reported relative to yearly average. The bold lines represent averages and the shaded areas represent 25 th to 75 th percentiles. 


\section{REFERENCES}

1 Krabbenhoft, D. P. \& Sunderland, E. M. Global Change and Mercury. Science 341, 1457-1458, doi:10.1126/science.1242838 (2013).

2 Driscoll, C. T., Mason, R. P., Chan, H. M., Jacob, D. J. \& Pirrone, N. Mercury as a global pollutant: sources, pathways, and effects. Environ. Sci. Technol. 47, 4967-4983, doi:10.1021/es305071v (2013).

3 Temme, C. et al. Trend, seasonal and multivariate analysis study of total gaseous mercury data from the Canadian atmospheric mercury measurement network (CAMNet). Atmos. Environ. 41, 5423-5441, doi:http://dx.doi.org/10.1016/j.atmosenv.2007.02.021 (2007).

$4 \mathrm{Fu}, \mathrm{X}$. W. et al. Observations of atmospheric mercury in China: a critical review. Atmos. Chem. Phys. 15, 9455-9476, doi:10.5194/acp-15-9455-2015 (2015).

5 Weigelt, A. et al. Analysis and interpretation of 18 years of mercury observations since 1996 at Mace Head, Ireland. Atmos. Environ.100, 85-93, doi:10.1016/j.atmosenv.2014.10.050 (2015).

6 Sprovieri, F. et al. Atmospheric Mercury Concentrations observed at ground-based monitoring sites globally distributed in the framework of the GMOS network. Atmos. Chem. Phys. Atmos. Chem. Phys. 16, 11915-11935, doi:10.5194/acp-16-11915-2016 (2016).

7 Holmes, C. D. et al. Global atmospheric model for mercury including oxidation by bromine atoms. Atmos. Chem. Phys. 10, 12037-12057, doi:10.5194/acp-10-120372010 (2010).

8 Song, S. et al. Top-down constraints on atmospheric mercury emissions and implications for global biogeochemical cycling. Atmos. Chem. Phys. 15, 7103-7125, doi:10.5194/acp-15-7103-2015 (2015).

9 Horowitz, H. M. et al. A new mechanism for atmospheric mercury redox chemistry: Implications for the global mercury budget. Atmos. Chem. Phys. 17, 6353-6371, doi:10.5194/acp-17-6353-2017 (2017).

10 Selin, N. E. et al. Chemical cycling and deposition of atmospheric mercury: Global constraints from observations. J. Geophys. Res.-Atmos. 112, doi:D0230810.1029/2006jd007450 (2007).

11 Slemr, F. et al. Comparison of mercury concentrations measured at several sites in the Southern Hemisphere. Atmos. Chem. Phys. 15, 3125-3133, doi:10.5194/acp-15-31252015 (2015).

12 Khalil, M. A. K. \& Rasmussen, R. A. Sources, sinks, and seasonal cycles of atmospheric methane. J. Geophys. Res.- Oceans 88, 5131-5144, doi:10.1029/JC088iC09p05131 (1983).

13 Rea, A. W., Lindberg, S. E., Scherbatskoy, T. \& Keeler, G. J. Mercury accumulation in foliage over time in two northern mixed-hardwood forests. Water Air Soil Pollut. 133, 49-67, doi:10.1023/a:1012919731598 (2002).

14 St Louis, V. L. et al. Importance of the forest canopy to fluxes of methyl mercury and total mercury to boreal ecosystems. Environ. Sci. Technol. 35, 3089-3098, doi:10.1021/es001924p (2001). 
15 Lindberg, S. et al. A Synthesis of Progress and Uncertainties in Attributing the Sources of Mercury in Deposition. Ambio 36, 19-32 (2007).

16 Smith-Downey, N. V., Sunderland, E. M. \& Jacob, D. J. Anthropogenic impacts on global storage and emissions of mercury from terrestrial soils: Insights from a new global model. J. Geophys. Res.-Biogeosci. 115, doi:10.1029/2009jg001124 (2010).

17 Obrist, D. Atmospheric mercury pollution due to losses of terrestrial carbon pools? Biogeochemistry 85, 119-123, doi:10.1007/s10533-007-9108-0 (2007).

18 Amos, H. M., Jacob, D. J., Streets, D. G. \& Sunderland, E. M. Legacy impacts of all-time anthropogenic emissions on the global mercury cycle. Global Biogeochem. Cycles 27, 410-421, doi:10.1002/gbc.20040 (2013).

19 Zhang, L. et al. The estimated six-year mercury dry deposition across North America. Environ. Sci. Technol. 50, 12864-12873, doi:10.1021/acs.est.6b04276 (2016).

20 Agnan, Y., Le Dantec, T., Moore, C. W., Edwards, G. C. \& Obrist, D. New constraints on terrestrial surface-atmosphere fluxes of gaseous elemental mercury using a global database. Environ. Sci. Technol. 50, 507-524, doi:10.1021/acs.est.5b04013 (2016).

21 Laacouri, A., Nater, E. A. \& Kolka, R. K. Distribution and uptake dynamics of mercury in leaves of common deciduous tree species in Minnesota, U.S.A. Environ. Sci. Technol. 47, 10462-10470, doi:10.1021/es401357z (2013).

22 Obrist, D. et al. Tundra uptake of atmospheric elemental mercury drives Arctic mercury pollution. Nature 547, 201-204, doi:10.1038/nature22997(2017).

23 Graydon, J. A., St. Louis, V. L., Lindberg, S. E., Hintelmann, H. \& Krabbenhoft, D. P. Investigation of mercury exchange between forest canopy vegetation and the atmosphere using a new dynamic chamber. Environ. Sci. Technol. 40, 4680-4688, doi:10.1021/es0604616 (2006).

24 Wang, X., Bao, Z., Lin, C. J., Yuan, W. \& Feng, X. Assessment of global mercury deposition through litterfall. Environ. Sci. Technol. 50, 8548-8557, doi:10.1021/acs.est.5b06351 (2016).

25 Zhang, Y. et al. Observed decrease in atmospheric mercury explained by global decline in anthropogenic emissions. Proc. Natl. Acad. Sci. USA, doi:10.1073/pnas.1516312113 (2016).

26 Demers, J. D., Blum, J. D. \& Zak, D. R. Mercury isotopes in a forested ecosystem: Implications for air-surface exchange dynamics and the global mercury cycle. Global Biogeochem. Cycles 27, 222-238, doi:Doi 10.1002/Gbc.20021 (2013).

27 Enrico, M. et al. Atmospheric mercury transfer to peat bogs dominated by gaseous elemental mercury dry deposition. Environ. Sci. Technol. 50, 2405-2412, doi:10.1021/acs.est.5b06058 (2016).

28 Jiskra, M. et al. Mercury deposition and re-emission pathways in boreal forest soils investigated with Hg isotope signatures. Environ. Sci. Technol. 49, 7188-7196, doi:10.1021/acs.est.5b00742 (2015).

29 Keeling, C. D. et al. Atmospheric carbon dioxide variations at Manua-Lao observatory, Hawaii. Tellus 28, 538-551 (1976).

30 Keeling, C. D., Chin, J. F. S. \& Whorf, T. P. Increased activity of northern vegetation inferred from atmospheric CO2 measurements. Nature 382, 146-149, doi:10.1038/382146a0 (1996). 
31 Denning, A. S., Fung, I. Y. \& Randall, D. Latitudinal gradient of atmospheric CO2 due to seasonal exchange with land biota. Nature 376, 240-243 (1995).

32 UNEP. Global Mercury Assessment 2013: Sources, Emissions, Releases and Environmental Tramsport. (UNEP Chemicals Branch, Geneva, Switzerland, 2013).

33 Steffen, A. et al. A synthesis of atmospheric mercury depletion event chemistry in the atmosphere and snow. Atmos. Chem. Phys. 8, 1445-1482 (2008). doi: 10.5194/acp-81445-2008

34 Diéguez, M. C. et al. Four years of atmospheric mercury records in Northwestern Patagonia (Argentina): potential sources, concentration patterns and influence of environmental variables observed at the GMOS EMMA station. Atmos. Chem. Phys. Discuss. 2017, 1-18, doi:10.5194/acp-2016-1076 (2017).

35 Fritsche, J. et al. Elemental mercury fluxes over a sub-alpine grassland determined with two micrometeorological methods. Atmos. Environ. 42, 2922-2933, doi:DOI 10.1016/j.atmosenv.2007.12.055 (2008).

36 Poissant, L., Pilote, M., Yumvihoze, E. \& Lean, D. Mercury concentrations and foliage/atmosphere fluxes in a maple forest ecosystem in Québec, Canada. J. Geophys. Res. 113, doi:10.1029/2007jd009510 (2008).

$37 \mathrm{Fu}, \mathrm{X}$. et al. Depletion of atmospheric gaseous elemental mercury by plant uptake at Mt. Changbai, Northeast China. Atmos. Chem. Phys. 16, 12861-12873, doi:10.5194/acp-16-12861-2016 (2016).

38 Wofsy, S. C. et al. Net exchange of $\mathrm{CO} 2$ in a midlatitude forest, Science, 260, 13141317, doi:10.1126/science.260.5112.1314 (1993).

39 Commane, R. et al. Seasonal fluxes of carbonyl sulfide in a midlatitude forest. Proc. Natl. Acad. Sci. USA 112, 14162-14167, doi:10.1073/pnas.1504131112 (2015).

40 Wehr, R. et al. Dynamics of canopy stomatal conductance, transpiration, and evaporation in a temperate deciduous forest, validated by carbonyl sulfide uptake. Biogeosciences 14, 389-401, doi:10.5194/bg-14-389-2017 (2017).

41 Obrist, D. et al. A synthesis of terrestrial mercury in the western United States: Spatial distribution defined by land cover and plant productivity. Sci. Total. Environ. 568, 522-535, doi:10.1016/j.scitotenv.2015.11.104 (2016).

42 Blasing, T. J., Broniak, C. T. \& Marland, G. The annual cycle of fossil-fuel carbon dioxide emissions in the United States. Tellus B 57, doi:10.3402/tellusb.v57i2.16779 (2011).

43 Lan, X., Talbot, R., Castro, M., Perry, K. \& Luke, W. Seasonal and diurnal variations of atmospheric mercury across the US determined from AMNet monitoring data. Atmos. Chem. Phys. 12, 10569-10582, doi:10.5194/acp-12-10569-2012 (2012).

44 Xu, X. H., Akhtar, U., Clark, K. \& Wang, X. B. Temporal variability of atmospheric total gaseous mercury in Windsor, ON, Canada. Atmosphere 5, 536-556, doi:10.3390/atmos5030536 (2014).

45 Song, S. et al. Constraints from observations and modeling on atmosphere-surface exchange of mercury in eastern North America. Elementa: Science of the Anthroposcene 4, doi:10.12952/journal.elementa.000100 (2016).

46 Bieser, J. et al. in Air Pollution Modeling and its Application XXIII (eds Douw Steyn \& Rohit Mathur) 189-195 (Springer International Publishing, 2014). 
47 Bieser, J. et al. Multi-model study of mercury dispersion in the atmosphere: vertical and interhemispheric distribution of mercury species. Atmos. Chem. Phys. 17, 69256955, doi:10.5194/acp-17-6925-2017 (2017).

48 Nemani, R. R. et al. Climate-driven increases in global terrestrial net primary production from 1982 to 1999. Science 300, 1560-1563, doi:10.1126/science.1082750 (2003).

49 Zhao, M. \& Running, S. W. Drought-induced reduction in global terrestrial net primary production from 2000 through 2009. Science 329, 940 (2010).

50 Campbell, J. E. et al. Large historical growth in global terrestrial gross primary production. Nature 544, 84-87, doi:10.1038/nature22030 (2017).

51 Baccini, A. et al. Estimated carbon dioxide emissions from tropical deforestation improved by carbon-density maps. Nature Clim. Change 2, 182-185, doi:10.1038/nclimate1354 (2012).

\section{CORRESPONDING AUTHOR:}

correspondence and requests for materials should be addressed to Martin Jiskra (martin.jiskra@unibas.ch)

\section{ACKNOWLEDGEMENTS:}

We thank those who are involved in the EMEP efforts and have contributed through operating sites, performing chemical analysis and by submissions of data to the data base EBAS. EMEP is funded through national contributions. We gratefully acknowledge the Air Quality Research Division of Environment Canada for the Total Gaseous Mercury data and the ESRL NOAA and WDCGG data centers for the $\mathrm{CO}_{2}$ data. This work was also funded by $\mathrm{H} 2020$ Marie SklodowskaCurie grant agreement No 657195 to MJ, European Research Council grant ERC-2010StG_20091028 and CNRS-INSU-CAF funding (PARCS project) to JES.

\section{AUTHOR CONTRIBUTIONS:}

MJ initiated the project, performed the data analysis and wrote the manuscript together with JES and contributions from DO, JB and AD. JB, RE, CML, KAP, IW, KK, DW, LM, CL, TM, MR, $\mathrm{OM}$, and AD provided data. All Authors read and commented on the manuscript. 


\section{METHODS:}

Atmospheric $\mathrm{CO}_{2}$ and $\mathrm{Hg}(0)$ measurements. The focus of the present analysis is on atmospheric monitoring sites that simultaneously measured $\mathrm{Hg}(0)$ and $\mathrm{CO}_{2}$ concentrations. As atmospheric oxidized mercury species account for a minor fraction of total atmospheric $\mathrm{Hg}$ ( $\left.\mathrm{Hg}_{\text {tot }}\right)$ in the PBL, no difference was made between $\mathrm{Hg}(0)$ and $\mathrm{Hg}_{\text {tot }}$ and all data are reported as $\mathrm{Hg}(0)$. High resolution QA/QC controlled $\mathrm{Hg}(0)$ and $\mathrm{CO}_{2}$ data were obtained from global air monitoring databases or directly from the responsible site scientists. The European data are harmonised and quality assured following the EMEP program and monitoring strategy. $\underline{52}$ $\mathrm{Hg}(0)$ concentrations at all sites except Pallas were measured at high frequency (5-15 min) using Tekran Continous Mercury Vapor Analyzers 2537 and reported as $1 \mathrm{~h}$ averages. For Cape Point, SA and Amsterdam Island, Fr all $\mathrm{Hg}(0)$ measurements were made in compliance with the GMOS quality assurance protocol (www.gmos.eu). $\mathrm{Hg}(0)$ concentrations at Pallas were measured using a semi-automatic sampling on Au-traps (quartz glass coated with gold) at an air sampling rate of $300 \mathrm{ml} / \mathrm{min}$ during $24 \mathrm{~h}$ periods, two days per week. The samples were analyzed on a Tekran 2500 CVAFS Mercury Detector at the IVL laboratory in Gothenburg. $\mathrm{CO}_{2}$ at Birkenes was measured with Cavity Ringdown spectroscopy (CRDS), Picarro G1301 with 5 $\mathrm{s}$ resolution, average to $1 \mathrm{~h}$ if data coverage was more than $75 \%$. The data are calibrated against WMO- Global Atmospheric Watch standards at EMPA. $\mathrm{CO}_{2}$ data from Amsterdam Island, Fr was measured using CRDS and from Egbert, Ca and Cape Point, SA using NonDispersive Infrared (NDIR) sensors. $\mathrm{CO}_{2}$ data from Schauinsland, De were measured by IRAbsorption. All data from Birkenes, No, Amsterdam Island, Fr, Egbert, Ca, Cape Point, SA and Schauinsland, De were measured continuously and reported as hourly averages. $\mathrm{CO}_{2}$ data from Pallas, Fi and Mace Head, Ir were measured on an event base with flasks and analysed using NDIR. $\underline{53}$ Monthly average $\operatorname{Hg}(0)$ data were obtained from. $, 6, \underline{43}, \underline{44}, \underline{54-61}$

Normal Differenced Vegetation Index, (NDVI) were obtained from the NASA Earth Observations (NEO) platform at 16 days and $0.1^{\circ}$ resolution. NDVI data are derived from Moderate Resolution Imaging Spectroradiometer (MODIS) images aboard the NASA's Terra and Aqua satellites.

\section{$\underline{\text { Statistics }}$}

Long-term trends of time series as well as linear regression's were calculated with the $\operatorname{Im}$ function and confidence intervals with the confint and predict functions of R. $\underline{62}$ Students ttests were performed with Microsoft Excel assuming uneven variances.

Seasonality of anthropogenic Hg emission. The monthly Hg emission for the different regions ( $\mathrm{F}(\mathrm{Hg})_{\text {month }}$ ) in $\mathrm{Mg} \mathrm{Hg} /$ month was calculated according to Formula 1: 
$\mathrm{F}(\mathrm{Hg})_{\text {month }}=f_{\text {coal }} * f_{\text {consumption }} * \mathrm{FHg}_{\text {year }}+\left(1-f_{\text {coal }}\right) * 1 / 12 * \mathrm{FHg}_{\text {year }}$

where $f_{\text {coal }}$ and $\mathrm{F}(\mathrm{Hg})_{\text {year }}$ corresponds to the fraction of $\mathrm{Hg}$ emission based on coal combustion and the total yearly Hg emission for each investigated country, based on the AMAP/UNEP 2010 mercury emission estimates. $\frac{32}{2} f_{\text {consumption }}$ corresponds to the monthly fraction of the yearly coal consumption. For the USA and Europe (27 EU countries) monthly coal consumption data are reported by governmental agencies. Seasonality of Hg emission from China was derived from the monthly power generation data between 2005 and 2010 reported by Liu et al. 2015. $\underline{63}$ The monthly cement production in China was considered constant throughout the year. $\underline{64}$

Normalization of monthly $\mathrm{Hg}$ concentration and emission data. In Figure 1 monthly $\mathrm{Hg}$ concentrations and emission fluxes are normalized to yearly averages for comparability. $\mathrm{Hg}$ concentrations are normalized as follows: $\mathrm{C}(\mathrm{Hg} 0)_{\text {monthx }} / \mathrm{C}(\mathrm{Hg} 0)_{\text {year, }}$ were $\mathrm{C}(\mathrm{Hg} 0)_{\text {monthx }}$ represents the multiyear monthly average of month $\mathrm{x}$ and $\mathrm{C}(\mathrm{Hg} 0)_{\text {year }}$ the yearly average.

Computation of Seasonal Amplitudes. The absolute seasonal amplitudes are calculated from the multiyear monthly averages as follows: $\left(\mu M_{\max }-\mu M_{\min }\right)$, were $\mu M_{\max }$ and $\mu M_{\min }$ represent the averages of the months with $\mathrm{NH}$ maximum (February for both $\mathrm{Hg}(0)$ and $\mathrm{CO}_{2}$ ) and minimum (August for $\mathrm{CO}_{2}$ and September for $\mathrm{Hg}(0)$ ) concentration (Table S6-S10), respectively. Relative amplitudes are calculated as follows: $\left(\mu \mathrm{M}_{\max }-\mu \mathrm{M}_{\min }\right) / \mu \mathrm{Y}$, were $\mu \mathrm{Y}$ represents the yearly average.

DATA SOURCES AND AVAILABILITY:

Most European $\operatorname{Hg}(0)$ data used are associated to EMEP, and publically available through the EMEP data base, EBAS: http://ebas.nilu.no. $\mathrm{CO}_{2}$ concentrations were obtained from the ESRL NOAA Global Monitoring Division database (ftp://aftp.cmdl.noaa.gov/data/trace_gases/co2/flask/surface/co2_mhd_surfaceflask_1_ccgg_event.txt, ftp://aftp.cmdl.noaa.gov/data/trace_gases/co2/flask/surface/co2_pal_surfaceflask_1_ccgg_event.txt) and the World Data Center for Greenhouse Gases WDCGG (http://ds.data.jma.go.jp/gmd/wdcgg/). Canadian $\mathrm{Hg}(0)$ concentrations were obtained from the National Atmospheric Chemistry (NAtChem) Database and Analysis Facility of Environment Canada (www.ec.gc.ca/natchem).

For the USA and Europe (27 EU countries) monthly coal consumption are reported by the U.S. Energy Information Administration (http://www.eia.gov/totalenergy, downloaded 25.5.2016) and Eurostat (http://ec.europa.eu/eurostat/statisticsexplained/index.php/Coal_consumption_statistics, downloaded 15.2.2016), respectively. 
NDVI data was obtained from the NASA Earth Observations (NEO) platform (http://neo.sci.gsfc.nasa.gov)

\section{References in Materials and Methods only}

52 Tørseth, K. et al. Introduction to the European Monitoring and Evaluation Programme (EMEP) and observed atmospheric composition change during 1972-2009. Atmos. Chem. Phys. 12, 5447-5481, doi:10.5194/acp-12-5447-2012 (2012).

53 Dlugokencky, E. J., P.M. Lang, J.W. Mund, A.M. Crotwell, \& M.J. Crotwell, a. K. W. T. Atmospheric Carbon Dioxide Dry Air Mole Fractions from the NOAA ESRL Carbon Cycle Cooperative Global Air Sampling Network, 1968-2015, <ftp://aftp.cmdl.noaa.gov/data/trace_gases/co2/flask/surface/> (2016).

54 Jiang, Y., Cizdziel, J. V. \& Lu, D. Temporal patterns of atmospheric mercury species in northern Mississippi during 2011-2012: Influence of sudden population swings. Chemosphere 93, 1694-1700, doi: 10.1016/j.chemosphere.2013.05.039 (2013).

55 Lan, X. et al. Seasonal and Diurnal Variations of Total Gaseous Mercury in Urban Houston, TX, USA. Atmosphere 5, 399-419, doi:10.3390/atmos5020399 (2014).

56 Cole, A. et al. A Survey of Mercury in Air and Precipitation across Canada: Patterns and Trends. Atmosphere 5, 635, doi:10.3390/atmos5030635 (2014).

57 Sheu, G. R. et al. Temporal distribution and potential sources of atmospheric mercury measured at a high-elevation background station in Taiwan. Atmos. Environ. 44, 2393-2400, doi:10.1016/j.atmosenv.2010.04.009 (2010).

58 Zhang, L., Wang, S. X., Wang, L. \& Hao, J. M. Atmospheric mercury concentration and chemical speciation at a rural site in Beijing, China: implications of mercury emission sources. Atmos. Chem. and Phys. 13, 10505-10516, doi:10.5194/acp-13-10505-2013 (2013).

59 Read, K. A. et al. Four years (2011-2015) of total gaseous mercury measurements from the Cape Verde Atmospheric Observatory. Atmos. Chem. Phys. 17, 5393-5406, doi:10.5194/acp-17-5393-2017 (2017).

60 Denzler, B. et al. Inversion Approach to Validate Mercury Emissions Based on Background Air Monitoring at the High Altitude Research Station Jungfraujoch (3580 m). Environ. Sci. Technol. 51, 2846-2853, doi:10.1021/acs.est.6b05630 (2017).

61 Howard, D. et al. Atmospheric mercury in the Southern Hemisphere tropics: seasonal and diurnal variations and influence of inter-hemispheric transport. Atmos. Chem. Phys. 17, 11623-11636, doi:10.5194/acp-17-11623-2017 (2017).

62 R: A Language and Environment for Statistical Computing (Vienna, Austria, 2015).

63 Liu, F. et al. High-resolution inventory of technologies, activities, and emissions of coal-fired power plants in China from 1990 to 2010. Atmos. Chem. Phys. 15, 1329913317, doi:10.5194/acp-15-13299-2015 (2015).

64 Zhu, J., Wang, T., Bieser, J. \& Matthias, V. Source attribution and process analysis for atmospheric mercury in eastern China simulated by CMAQ-Hg. Atmos. Chem. Phys. 15, 8767-8779, doi:10.5194/acp-15-8767-2015 (2015). 